\title{
EFFECT OF PREMEDICANTS, INTRAVENOUS ANAESTHETIC AGENTS AND LOCAL ANAESTHETICS ON PHAGOCYTOSIS IN VITRO
}

\author{
G.C. MOUDGIL
}

\begin{abstract}
Intact leucocyte function is essential for the body's defense against infection. Any depression of leucocyte migration, phagocylosis and ability to kill invading organisms is likely to enhance murbidity and mortality from infection in the postoperative period. Although volatile anaesthetic agents have been shown to influence the leucocyte function adversely, yet the effects of non-volatile anaesthetic agents and other allied drugs on the leucocyte phagocytic activity have not been explored. Therefore, the effects of premedicants (morphine, meperidine, diazepam), intravenous induction agents (thiopentone, methohexitone, alfathesin, and ketamine), local anaesthetic agents (lidocaine, procaine, and bupivacaine), muscle relaxants (succinylcholine and tubocurarine), and other drugs (prednisolone, furosemide, aspirin, epinephrine and chlorpromazine), on the phagocytic activity of leucocytes was investigated in vitro.

Leucocytes were separated from the blood samples taken from healthy human volunteers, treated with $10^{-2}$ to $10^{-6}$ molar concentrations of the drug under investigation and subsequently incubated at $37^{\circ} \mathrm{C}$ along with heat inactivated staphylococcus aureus to allow phagocytosis. Following incubation for one hour, cell smears were prepared and stained with haematoxylin. The number of bacteria ingested by one hundred leucocytes on the control and the drug treated cell smears were counted. The difference in phagocytosis between the control and the test cells when examined by analysis of variance revealed a statistically significant dose dependent inhibition of phagocytic activity under the influcnce of premedicants, intravenous induction agents, local anaesthetic agents (except bupivacaine), diazepam and chlorpromazine $(\mathrm{P}<0.005)$. In contrast, muscle relaxants and other drugs failed to inhibit the leucocyte phagocytic activity in vitro.

These observations indicate that different anaesthetic agents can adversely effect the leucocyte function in vitro; however, the mechanisms by which these agents produce a depression of phagocytosis are not clear at present.
\end{abstract}

Key Words: Phagocytosis; Premedication; Anaesthetic Agents, intravenous, local.

INTACT LEUCOCYTE FUNCTION characterised by chemotactic migration, phagocytosis and the ability to kill invading organisms is the most important variable in the immunologic defense against infections.' Any depression of these paramaters of leucocyte function is likely to increase the incidence of infection. The possibility that anaesthetic agents may enhance the incidence of infection was considered as early as 1903 when Snel reported that ether, chloroform and chloral hydrate increased the mortality from anthrax in guinea pigs. ${ }^{2}$ Recent reviews of the literature suggest that anaesthetic agents can depress different components of the immune response $^{3,4}$ and, based on this hypothesis, our previous investigation revealed that different

G.C. Moudgil, M.B., B.S., M.S.c., F.F.A.R.C.S.; Assistant Professor in Anaesthesia, McMaster University, 1200 Main Street West, Hamilton, Ontario, Canada, L8N 3 Z5.

Can. Anaesth. Soc. J., vol. 28, no. 6, November 1981 local, intravenous and volatile anaesthetic agents inhibited leucocyte locomotion in a dose dependent manner in vitro. ${ }^{5} \mathrm{~A}$ similar depression of leucocyte chemotactic migration has also been observed in vivo during and after surgery. ${ }^{6}$ However, contradictory data have also been reported, where chemotactic migration was not affected adversely by anaesthetic agents. ${ }^{7}$ There also appears to be a diversity of opinion regarding the effects of anaesthesia on the leucocyte phagocytic activity. Some workers have reported a depression of phagocytosis following halothane anaesthesia in mice ${ }^{8}$ and man, ${ }^{9}$ while others failed to observe any depression of phagocytosis following halothane and nitrous oxide anaesthesia in man. ${ }^{10}$ To date relatively little is known about the effects of narcotics, local and intravenous anaesthetic agents. Therefore the effect on the leucocyte phagocytic activity of these and other drugs commonly used during anaesthesia has been investigated in vitro. 


\section{Materials and Methods}

\section{Preparation of Leucocytes}

Heparinized peripheral venous blood samples $(20 \mathrm{mls})$ were obtained from healthy human volunteers. Dextran 110 was added to the samples (one part dextran: 10 parts of blood) and the erythrocytes were allowed to sediment at room temperature for one hour. The cell rich supernatant plasma was aspirated and the leucocytes were separated by centrifugation at $400 \mathrm{~g}$ for 10 minutes. The cells were washed twice in Gey's balanced salt solution at $\mathrm{pH} 7.2$." The cell viability was ascertained by trypan blue "dye exclusion test" and the cells were resuspended in plasma to give a final count of approximately $10^{6}$ cells/ml. The $\mathrm{pH}$ of this cell suspension was adjusted to 7.2 .

\section{Preparation of Bacteria}

Staphylococcus aureus was grown on nutrient agar plates and the colonies were harvested after 24 hours. The bacteria were inactivated by heat at $65^{\circ} \mathrm{C}$ for 30 minutes and a bacterial suspension was prepared to give a bacterial count of approximate $4-5 \times 10^{6} / \mathrm{ml}$.

\section{Phagocytosis Assay}

Half $\mathrm{ml}$ aliquots of leucocyte suspension were dispensed into different test tubes. Heat inactivated staphylococcus aureus was added to each test tube to give an approximate ratio of four bacteria to one leucocyte. Having allowed for appropriate controls (no drug), the drug under investigation was added to the test cell suspensions to give final drug concentrations ranging from $10^{-2}$ to $10^{-6}$ molar. All the test tubes were mounted on a mechanical rotator to allow homogenous mixing of the bacteria and the cells and the entire assembly was incubated at $37^{\circ} \mathrm{C}$ for one hour. Following incubation, thick smears were prepared from each test tube and stained with haematoxylin. The smears were examined under a microscope using an oil immersion lens. The number of bacteria ingested by one hundred leucocytes on the control and the test smears were counted. All smears were examined by the same observer and the observer was blind to the identity of individual smears. The effect of each drug on the phagocytic activity of leucocytes obtained from six different healthy human volunteers was investigated.

The difference in phagocylosis between the control and the test cells was examined for significance by analysis of variance.

\section{RESULTS}

The leucocytes obtained from different individuals varied in their phagocytic activity, this being representative of each individual's inherent phagocytic activity.

The effects of in vitro exposure to different concentrations of intravenous anaesthetic agents is shown in Figure 1. Following exposure to different concentrations of thiopentone, alfathesin, and ketamine, a dose dependent inhibition of phagocytic activity was observed with each drug. This depression of phagocytosis was statistically significant when compared with the control phagocytic activity ( $\mathrm{p}<0.005$ ). A similar depression of phagocytic activity was also observed with methohexitone (Table I). The extent of this depression was identical with all the drugs tested.

The effects of three local anaesthetic agents, (lidocaine, procaine and bupivacaine) are illustrated in Figure 2. A dose dependent and statistically significant depression was observed with lidocaine and procaine, but a similar depression was not observed with bupivacaine except at very high concentrations $\left(10^{-2} \mathrm{M}\right)$.

A similar dose-dependent inhibition of phagocytic activity was observed when leucocytes were exposed to different concentrations of meperidine and morphine (Figure 3). Both drugs produced identical depression of phagocytic activity $(p<0.005)$. Diazepam and chlorpromazine also produced a dose-dependent significant depression of phagocytic activity $(p<0.005)$. The phagocytic activity was completely abolished following exposure to $10^{-2}$ molar concentration of both these drugs (Figure 4).

These observations indicate that intravenous anaesthetic agents, narcotics, diazepam, chlorpromazine, and local anaesthetic agents (except

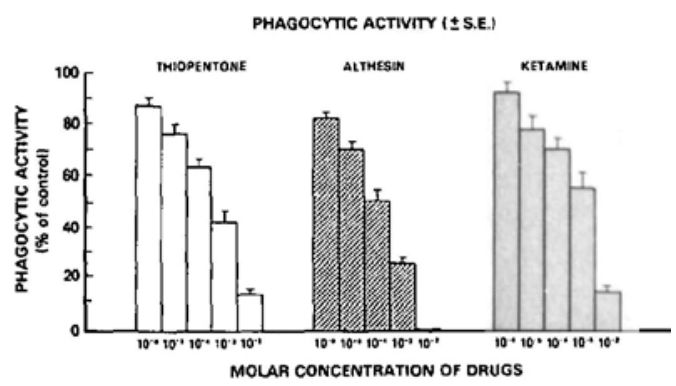

FIGURE 1 Dose-dependent inhibitory effect on the leucocyte phagocytic activity produced by intravenous anaesthetic agents. The phagocytic activity has been expressed as percentage of the control activity. 
TABLE I

Effect of anaesthetic Agents and Other Non-Depressant Drugs on Phagocytosis. Phagocytic Activity Has Been Expressed as Percentage of Control Activity (No Drug) \pm S. E.

\begin{tabular}{lccccc}
\hline \hline \multicolumn{1}{c}{ Drug } & $10^{-6}$ Molar & $10^{-5}$ Molar & $10^{-4}$ Molar & $10^{-3}$ Molar & $10^{-2}$ Molar \\
\hline Tubocurarine & $95.62 \pm 4.41$ & $89.91 \pm 3.75$ & $90.53 \pm 1.97$ & $87.00 \pm 2.24$ & 0 \\
Succinylcholine & $88.56 \pm 2.29$ & $88.23 \pm 2.29$ & $87.21 \pm 1.82$ & $87.04 \pm 1.72$ & $87.25 \pm 1.90$ \\
Predniosolone & $91.87 \pm 5.37$ & $92.44 \pm 6.08$ & $90.43 \pm 5.92$ & $91.75 \pm 3.55$ & $93.28 \pm 4.81$ \\
Epinephrine & $90.42 \pm 4.84$ & $89.71 \pm 4.51$ & $88.74 \pm 5.25$ & $90.19 \pm 6.1$ & 0 \\
Furosemide & $93.74 \pm 5.60$ & $88.23 \pm 4.66$ & $99.46 \pm 6.62$ & $90.68 \pm 5.60$ & $88.13 \pm 6.72$ \\
Aspirin & $92.49 \pm 1.56$ & $95.93 \pm 1.23$ & $93.41 \pm 1.59$ & $91.81 \pm 1.41$ & $91.57 \pm 1.94$ \\
Methohexitone & $83.34 \pm 5.65$ & $73.63 \pm 5.08$ & $63.63 \pm 6.47$ & $47.08 \pm 4.30$ & $23.42 \pm 2.41$ \\
\hline
\end{tabular}

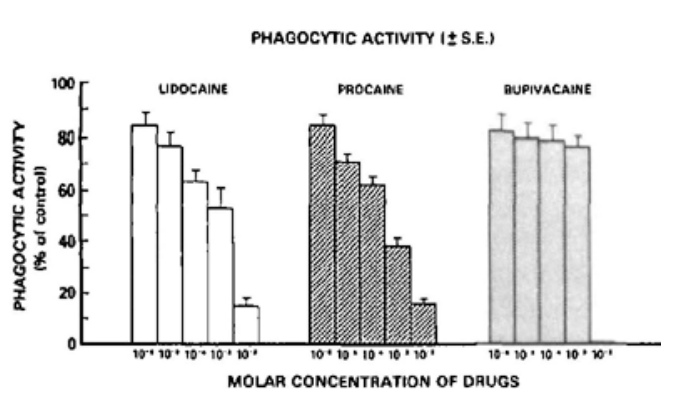

Figure 2 Dose-dependent inhibitory effect on the leucocyte phagocytic activity produced by three local anaesthetic agents. The phagocytic activity has been expressed as percentage of the control activity.

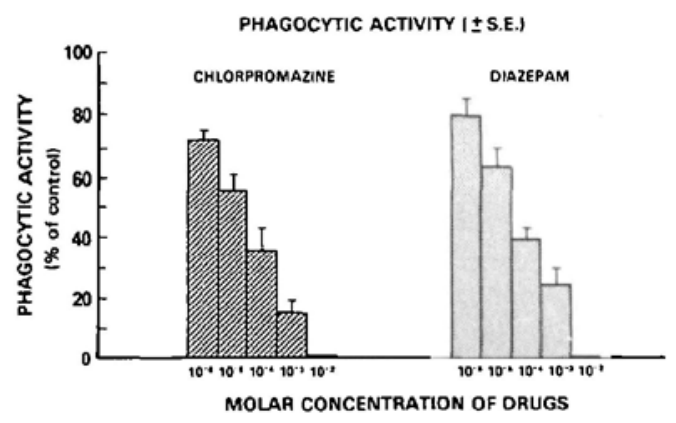

FIgure 3 Dose-dependent inhibitory effect on the leucocyte phagocytic activity produced by meperidine (Demerol ${ }^{(1)}$ ) and morphine. The phagocytic activity has been expressed as percentage of the control activity.

bupivacaine) produce a dose-dependent, significant depression of human leucocyte phagocytic activity in vitro.

In contrast, when leucocytes were exposed to different concentrations of muscle relaxants, furosemide, prednisolone, aspirin, or epinephrine, the phagocytic activity was not affected adversely (Table I). Thus it would appear that the drugs that do not depress the central nervous system also fail to depress phagocytosis. Furthermore, the depression observed with narcotics, local and intravenous anaesthetic agents

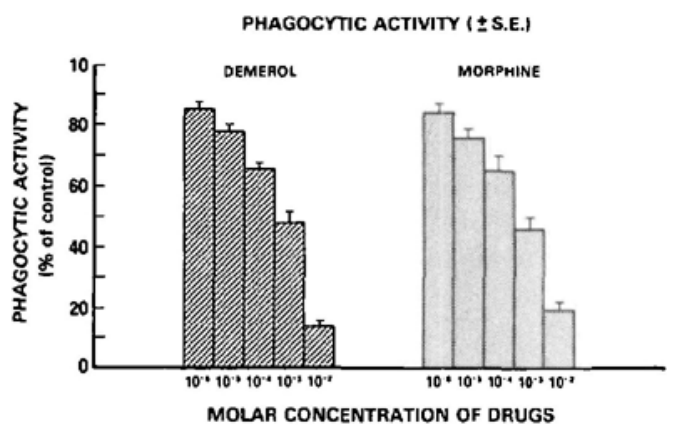

Figure 4 Dose-dependent inhibitory effect on the leucocyte phagocytic activity produced by chlorpromazine and diazepam. The phagocytic activity has been expressed as the percentage of the control activity.

was not due to non-specific concentration effects of the drugs under investigation, since leucocyte exposure to identical molar concentrations of drugs such as aspirin or furosemide did not depress the phagocytic activity.

\section{Discussion}

The migration of leucocytes towards inflamed or injured tissues is one of the earliest events among the body defense systems. To combat an invading organism effectively, these cells must have a sense of direction as well as the ability to phagocytose and kill the offending organisms. This phagocytic activity of human leucocytes remains the most important variable in the body's defense against infection. Any depression of leucocyte chemotactic migration, phagocytic and/or bactericidal activity is likely to enhance the incidence of infection. Since infection in the period following surgery is still common, it is important that the effect of anaesthetic agents in the pathogenesis of infection be clearly defined.

To date, only the effects of different volatile and gaseous anaesthetic agents on the phagocytic activity have been investigated $\mathrm{d}^{\mathbf{8} 9,10}$ and the evidence cited for and against the adverse effects of 
these agents remains contradictory. In the present study, the effects on human leucocyte phagocytic activity of local and intravenous anaesthetics, narcotics and other drugs commonly used during anaesthesia have been assessed by using a morphological technique. The phagocytosis assay used in this study has the advantage of simplicity, low cost, and reproducibility, but has the disadvantage of being unable to detect either the rate of ingestion or the bactericidal activity. Therefore the data presented in this study represent only the effects of the drugs examined on the ingestion process in vitro and should not be extrapolated to the bactericidal activity.

Given the limitations of this assay system, this study had revealed that intravenous anaesthetic agents, local anaesthetic agents, narcotics, diazepam and chlorpromazine all produce a dosedependent and statistically significant inhibition of phagocytic activity in vitro.

All the intravenous anaesthetic agents produced an identical dose-related inhibition of phagocytic activity, including the concentrations usually achieved during clinical anaesthesia. Since the cells had been resuspended in plasma, the proportions of the free and the protein bound fractions of these drugs should be similar to those observed following intravenous administration. A key question is the relevance of the drug concentrations investigated in vitro in the present study to the drug concentrations which could be expected in clinical situation in vivo. Following intravenous administration of $3.5 \mathrm{mg} \cdot \mathrm{kg}^{-1}$ of thiopentone, ${ }^{12} 3.0 \mathrm{mg} \cdot \mathrm{kg}^{-1}$ of methohexitone infusion ${ }^{13}$ and $60-70 \mu \mathrm{l} \cdot \mathrm{kg}^{-1}$ of alfathesin, ${ }^{14}$ serum concentrations of $4.0 \mu \mathrm{g} / \mathrm{ml}, 3.8 \mu \mathrm{g} / \mathrm{ml}$, and $3.0 \mu \mathrm{g} / \mathrm{ml}$, respectively have been reported. These serum concentrations are similar to those investigated in this study. Thus it would appear that concentrations of these drugs achieved during clinical anaesthesia may adversely affect the leucocyte phagocytic activity. However, in the clinical situation, the serum concentrations of the drugs gradually decline with time and are not constant like those used in the present in vitro study. Therefore further investigations into the adverse effects of these drugs in the clinical situation are desirable. These data only reveal that intravenous anaesthetic agents inhibit the leucocyte phagocytic activity in a dose dependent manner in vitro.

Among the local anaesthetic agents investigated, a depression of phagocytic activity was observed only following exposure to different concentrations of lidocaine and procaine and no significant depression in phagocytosis was observed with bupivacaine. This difference may have resulted from differences in protein binding characteristics of the agents. Since bupivacaine is 95 per cent bound to serum proteins compared to 65 per cent protein binding for lidocaine, ${ }^{15}$ it is possible that the concentration of the free drug required to inhibit phagocytosis was not reached with bupivacine. At very high concentrations of bupivacaine $\left(10^{-2} \mathrm{M}\right)$ a highly significant depression of phagocytosis was observed. The depression observed at this concentration was not due to cell death or toxicity since the cells were viable, as ascertained by trypan blue dye exclusion test. The relevance of the drug concentrations used in this study to those achieved in clinical practice is rather complex. A wide variety of factors, such as site of injection. concentration, total dose, presence of a vasoconstrictor, rate of injection, redistribution in tissues, plasma protein binding, and the rate of metabolism, all influence the ultimate plasma concentration of the drug. However, Mazze and Dunbar ${ }^{16}$ have reported plasma lidocaine concentrations of 1.5 $\pm 0.2 \mu \mathrm{g} / \mathrm{ml}, 2.5 \pm 0.5 \mu \mathrm{g} / \mathrm{ml}$, and $3.1 \pm 0.7 \mu \mathrm{g} / \mathrm{ml}$ following intravenous regional anaesthesia, axillary block and lumbar epidural anaesthesia, respectively. Although such plasma concentrations do not produce signs of systemic toxicity yet these concentrations are similar to those used in the present study. Therefore it is conceivable that they may also affect the leucocyte function adversely in the clinical situation. The duration of such depression of phagocytic activity or the reversal thereof are not known at present.

Among narcotics, both morphine and meperidine produced identical dose-dependent inhibition of phagocytic activity. However, the concentrations used are higher than those commonly achieved following a single administration of these drugs. This depression could be relevant in situations where large repeated doses of these agents are employed in clinical practice of anaesthesia. The narcotic-induced depression of phagocytic activity at high serum concentrations of these drugs could be of relevance in open heart surgery, where massive doses of narcotics are routinely utilized. To date, nothing is known about the effects of massive dose narcotic administration in open heart surgery on the host's defense mechanisms and such investigations could be a fertile field for research.

In vitro exposure to varying concentrations of diazepam and chlorpromazine also resulted in a 
dose-dependent inhibition of phagocytic activity and, at the highest concentrations of these drugs, phagocytosis was completely abolished.

In contrast, when leucocytes were exposed to myoneural blocking agents, or other drugs shown in Table I, there was no depression of phagocytic activity.

The depression observed with narcotics, local and intravenous anaesthetic agents is unlikely to be due to non-specific concentration effects of these agents, since exposure to equimolar concentrations of drugs shown in Table I failed to produce a similar non-specific depression of phagocytosis. It is interesting to observe that all the drugs that caused a depression of the central nervous system also caused a depression of phagocytic activity. The present study illustrates that many of the non-volatile anaesthetic agents consistently produced a dose dependent inhibition of phagocytosis in vitro. In the previous studies of volatile agents by Bruce $^{8}$, a similar depression of phagocytosis was also reported. However, in contrast, Cullen, et al. ${ }^{10}$ could not detect a significant depression of phagocytic activity following in vitro equilibration of leucocytes with halothane and nitrous oxide. Since the concentration of volatile agents is likely to decline during the test procedure, it is possible that the latter findings may have resulted from recovery of leucocytes during the test procedure. Unlike volatile agents, the concentration of drugs tested in the present study remained constant throughout the test procedure and this could account for the consistent depression of phagocytosis observed in the present investigation.

The mechanisms producing this depression of phagocytosis are not clear. During phagocytosis two phases have been recognized - the attachment phase and the ingestion phase. ${ }^{17}$ These phases may each require different recognition mechanisms. It is possible that the agents producing depression of phagocytosis do so by affecting either of these two phases. Therefore, it is desirable that future studies should explore the effects of different anaesthetic agents at the cellular and subcellular level, to clarify the mechanisms of anaesthetic drug-induced depression of phagocytic activity. Whether the drugs investigated in the present study could have affected any of these steps associated with phagocytosis remains to be clarified.

\section{REFERENCES}

1. Alexander, J.W. Host defense mechanisms against infection. Surg. Clin. N. Amer. 52: 1367 (1972).

2. SNEL, J.J. Immunitat und narkose. Berlin Klin. WSCHR. 40: 212 (1903).

3. MoudgiL, G.C. \& WADE, A.G. Anaesthesia and immunocompetence. Brit. J. Anaesth. 48: 31 (1976).

4. Duncan, P.G., Cullen, B.F. Anesthesia and immunology. Anesthesiology, 45: 522, 1976.

5. Moudgil, G.C., Allan, R.B., Russell, R.J. \& WILKINSON, P.C. Inhibition, by anaesthetic agents, of human leucocyte locomotion towards chemical attractants. Brit. J. Anaesth. 49: 97 (1977).

6. Stanley, T.H., Hill, G.E., Portas, M.R., Hogan, N.A. \& HILL, H.R. Neutrophil chemotaxis during and aftergeneral anesthesia and operating. Anes. Anal.. 55: 668 (1976).

7 Duncan, P.G. \& Cullen, B.F. Neutrophil chemotaxis and anaesthesia. Brit. J. Anaesth. 49: 345 (1977).

8. BRUCE, D.L. Effect of halothane anaesthesia on experimental salmonella peritonitis in mice. $J$. Surg. Res., 7: 180 (1967).

9. Kosciolek, E. Fagocytarna aktywnosc leukocytow krwi i wysieky otrzequnowego $w$ ogolnym znieczuleniu fluotanowym. Rocz. Pomor. Akad. Med. 13: 149 (1967).

10. CULLEN, B.F. The effect of halothane and nitrous oxide on phagocytosis and human leukocyte metabolism. Anesth. Analg. (Cleve.). 53: 531, (1974).

11. WILKINSON, P.C. Chemotaxis and inflammation. P. 168. Edinburgh: Churchill Livingston (1974).

12. Ghoneim, M.M. \& Van Hamme, M.J. Pharmacokinetics of thiopentone: Effects of enflurane and nitrous oxide anaesthesia and surgery. Brit. J. Anaesth. 50: 1237 (1978).

13. BREimer, D.D. Pharmacokinetics of methohexitone following intravenous infusion in humans. Brit. J. Anaesth. 48: 643 (1976).

14. Simpson, M.E. Pharmacokinetics of althesin comparison with Lidocaine. Brit. J. Anaesth. 50: 1232 (1978).

15. Covino, B.G. \& Vassalo, H.G. Local anesthetics. Mechanism of action and clinical use. Grune \& Stratton Inc., New York (1976).

16. Mazze, R.E. \& Dunbar, R.W. Plasma lidocaine concentrations after caudal, lumbar epidural, axillary block, and intravenous regional anesthesia. Anesthesiology, 27: 574 (1966).

17. Hirsch, J.G. The phagocytic defence system Symposium of the Society for General Microbiology $22: 59$ (1972).

\section{RÉSUMÉ}

La défence contre l'infection exige de l'orginisme une fonction leucocytaire intacte. Toute dépression de la capacité de migration, phagocytose et d'extermination des microorganismes envahisseurs est susceptible d'augmenter la morbidité et la mortalité causées par l'infection 
en période post-opératoire. Bien qu’il ait déjà été démontré que les agents anesthésiques volatiles influencaient défavorablement la fonction leucocytaire, jusqu'à maintenant les effects des agents non volatiles et des autres médicaments utilisés en anesthésie n'ont jamais fait l'objet d'études particuljères en autant que le comportement de l'activité phagocytaire des leucocytes est concernée. C'est pour quoi l'auteur s'est attaqué à étudier sur cette fonction des effets de la prémédication (morphine, mépéridine, diazepam), des agents à induction par la voie veineuse (thiopentone, méthohexitone, alfathésin et kétamine), des agents anesthésiques locaux (lidocaïne, procaïne, et bupivacaïne), des myorésolutifs (succinylcholine tubocurarine), et d'autres médicaments (prednisolone, furosémide, aspirin, épinéphrine, et chlorpromazine).

On a séparé les leucocytes obtenus du sang de volontaires en bonne santé, on les a mis en présence de concentrations molaires $10^{-2}$ à $10^{-6}$ du médicament à l'étude et on les a par la suite incubés à $37^{\circ} \mathrm{C}$ avec des staphylocoques dorés inactivés à la chaleur dans le but de faciliter la phagocytose; après une heure d'incubation, des frottis de cellules ont été préparés et colorés à l'haematoxylin; finalement on a comparé le nombre de bactéries ingérées sur les frottis traités avec le nombre de bactéries ingérées par cent leucocytes sur les contrôles. La différence entre les deux a été soumise à une analyse de variance qui a révélé unc inhibition significative de la phagocytose proportionnelle à la dose du médicament utilisé pour la prémédication, les agents d'induction par la voie veineuse, les anesthésiques locaux (à l'exception de la bupivacaine) et la chlorpromaxine $(\mathrm{p}<0.005)$. Par contre, les myorésolutifs et les autres médicaments mentionnés plus haut n'ont pas modifé l'activité phagocytaire des leucocytes in vitro. 